\title{
Takaful and Micro Takaful: A Key Factor of Reduction of Poverty and Undernourishment
}

\author{
Sawssen $\mathrm{Nafti}^{1 *}$ \\ ${ }^{1}$ Faculty of Economics and Management of Sousse Laboratory, University of Sousse Street of Khalifa El Karoui Sahloul - BP n $526-$ \\ 4002 Sousse, Tunisia
}

\begin{abstract}
DOI: $10.36348 /$ sjef.2022.v06i01.002
| Received: 30.12.2021 | Accepted: 06.01.2022 | Published: 10.01.2022

*Corresponding author: Sawssen Nafti

Faculty of Economics and Management of Sousse Laboratory, University of Sousse Street of Khalifa El Karoui Sahloul - BP $n^{\circ} 526$ 4002 Sousse, Tunisia
\end{abstract}

\section{Abstract}

This paper examines the relationship between Takaful, micro Takaful and reduction of poverty and undernourishement. Our analysis is based on a theoretical study aimed to know if Takaful is a good solution to the poverty and undernourishment problems in Islamic economy or a simple component of islamic assurance.Our study shows that Takaful is an effective solution to the problem of poverty in islamic economy in the long term, Takaful have an important role to reducing poverty risks, Without protection against losses and natural risks or protection of their persons, their life, their property and their health, many people find themselves regularly falling back into poverty which is not only prejudicial to them but also renders development assistance ineffective in the long term. Also Takaful is a good solution to reduce undernourishement in islamic economy.

Keywords: Takaful-Micro Takaful-Islamic economy-development-Poverty-Undernourishment.

JEL Classification: D63- I3-J6- N3.

Copyright () 2022 The Author(s): This is an open-access article distributed under the terms of the Creative Commons Attribution 4.0 International License (CC BY-NC 4.0) which permits unrestricted use, distribution, and reproduction in any medium for non-commercial use provided the original author and source are credited.

\section{INTRODUCTION}

Some Muslim countries today find themselves in a state of structural and multidimensional underdevelopment and suffer from poverty, undernourishment, social ills and economic and social tensions. This blockage to development is the result of their estrangement from Islam, which is the source of values such as solidarity, justice ... Therefore, neither the capitalist system, nor the Marxist system are capable of providing lasting and relevant solutions to the problems of Muslim countries especially in Africa and Asia, only the return to Islam which is capable of offering solutions.

Islamic "Takaful" insurance is considered to be, within the Muslim community, the most popular social institution aimed to combating impoverishment and misery. "Takaful" being the form of insurance considered by "shari'a" / Islamic law to be acceptable to Muslims. Without coverage against disasters and against natural risks to their person, their life, their property or their health, a large number of people regularly fall back into poverty which is not only bad for them but makes development aid ineffective in the long run. "Takaful" can provide communities with a safety net that enables them to achieve a lasting improvement in their standard of living by providing families with the basics to look to the future with a sense of security and optimism. Our study begins by a literature review of takaful, then, introducing the concept of takaful, the origins and the history of the insurance; after that we investigate its different models and the relation between Takaful and poverty.

\section{LITERATURE REVIEW}

Islamic insurance Takaful is considered as the most popular social institution in the Islamic community which aim is to counter poverty and deprivation. Takaful is the form of insurance deemed to be permissible for Muslims under charia law (Islamic Law). Without protection against losses and natural risks or protection of their persons, their life, their property and their health, many people find themselves regularly falling back into poverty which is not only prejudicial to them but also renders development assistance ineffective in the long term. Takaful can provide the safety net for communities to achieve 
Sawssen Nafti., Saudi J Econ Fin, Jan, 2022; 6(1): 7-10

sustainable development of their standard of living as it provides the families with a basis for looking to the future with a sense of security and optimism.

The literature on Islamic development methodology has dealt with aspects that characterize the model and distinguish it from capitalist and socialist models and which will have an impact on the identity of a new thought such as the public / private property relationship, and the law. poor. Najatullah Siddiki, shows that economic thought in Islamic literature dates from the time of Ibn Khaldoun (1332-1406), Ibn Taymeya (1262-1328), Abu Youssef (731-798) and others. Ibn Khaldoun, in his "Introduction", treated economics as a branch of his new science interested in the study of human behavior and did not add the adjective "Islamic" to it. The Islamic character has recently been added to economics when recent literature has added to it the application of general rules in the Qur'an and Sunnah, which indeed are not numerous. In the early 1940s, Muslim economists revisited economics from an Islamic perspective. Since then, the literature on Islamic economics has developed. This new approach to development has found its sources in the doctrine founded by scholars through case law and personal efforts in the interpretation of sacred texts (Quran and Sunnah) including socioeconomic provisions. The literature on socioeconomic development from an Islamic perspective has grown significantly since the 1970s from different angles. From then on, she dealt with the basic needs of the human being in this methodology, the impact of zakat and social investments on poverty, relations between Islamic banks and development, etc. Here, development from an Islamic perspective is seen to show its relation to the purpose of private equity management by introducing stakeholders to a formula that they recognize in their language and religion. Moreover, it is a divine obligation of result which must be reactivated among the Arab peoples to develop an active rather than a passive behavior, that is to say not to wait for the development to be put in place by their governments. It is also a question of showing how the theory treats the essential needs of the human being to reduce the concrete vision for the new company, including its potential fields of action. He then explains why knowledge is chosen as being a fundamental need for the real development of this region. Finally, the importance given in this methodology to poverty is discussed to show its relation with the investment philosophy of the management of Islamic funds.

\section{Notion, history and models of takaful \\ 1. Notion and history of takaful}

Takaful is the form of insurance deemed to be permissible for Muslims under charia law (Islamic Law). To simplify, we could say that Takaful is an insurance operation (since the technical bases are the same) which is done on a mutual basis and in accordance with the principles of Sharia. The concepts of Takaful, cooperative or Islamic insurance are used by professionals and cover - broadly speaking: The "Takaful" is the most popular concept.

- Pioneer phase: Islamic insurance was launched in 1979 in Sudan and Saudi Arabia

- From 1984, expansion of Takaful in Malaysia and in certain countries of the Far East, and the generalization of the use of the concept of Takaful.

- From 2004, Takaful experienced a real boom in the Far and Middle East, following the increase in oil prices and the boom in Islamic finance. Thus, new Takaful companies have emerged in different countries: United Kingdom, South Africa, Saudi Arabia, Kuwait, United Arab Emirates and Malaysia.

\section{Takaful models}

In Takaful, there is a clear separation between the shareholders of the company and the members. Members donate their contributions, which remain the property of the fund; and the shareholders act as operator on behalf of the members. In addition to the income from the capital investment, the operator (shareholders) receives the following remuneration in return for the management of the fund:

a. Moudharaba (sharing of financial profits) on the investment or all insurance operations according to the model chosen, and only after approval by the Religious Council.

b. The sharing of technical profits, but this will depend on the acceptance or not by the religious council.

Generally speaking, the distribution will be different depending on the Takaful model adopted.

There are mainly 3 main models: Moudharaba, Wakala and cooperative. A model called Waqf is used by a few companies.

- Al Moudharaba (profit sharing) is used mainly in the Far East.

- Al Wakala: Management fees (in percentage) taken in advance from all contributions. This model is widely used in the Middle East.

The current trend in the Middle East is for the combination of two models, namely:

- Wakala for the subscription.

- Moudharaba for investment

\section{The cooperative model}

Saudi Arabia: The new law of 2004 subjects all companies to the cooperative model and requires the separation of funds and the distribution of technical profit.

Sudan: all companies are Islamic / cooperative by law, and shareholders are not allowed to benefit from technical profit. 


\section{Islamic Insurance Industry Statistics}

The number of Takaful companies has gradually increased since 2004 to currently reach 179 and their market share is increasing significantly. The biggest market success in terms of penetration of Takaful vs. Conventional (6\% in 2007), and also in terms of legal framework and political support is Malaysia. Sudan, Saudi Arabia, Bahrain and Pakistan have also adopted a specific legal framework for Takaful. Saudi Arabia, by adopting the cooperative model in 2004 by imposing it on all approved companies, is now one of the main Islamic countries in terms of volume of contributions (USD 2.4 billion in 2007), In the countries of the Gulf Cooperation Council (GCC), there has been a significant evolution of Takaful in recent years due to the number of new Takaful companies (10 in Kuwait, 7 in the United Arab Emirates, 3 in Qatar, 6 in Bahrain, and 25 in Saudi Arabia under the 2004 law. In Pakistan, there is a legal regime for Takaful and three companies have been started in the past four years. Indonesia is the largest Muslim country and also the largest country in terms of "Islamic windows" or departments under conventional operators (around 30). On the other hand, there are only two full Takaful operators.

Takaful in Africa is still limited to a few territories mainly in Egypt and Sudan. The latter country, at the origin of the first Islamic company, adopted regulations based on Sharia law and companies must follow the cooperative model. In Egypt, new companies have been launched in recent years and others are likely to start operations in 2009, which will undoubtedly increase Takaful's penetration.

\section{Reasons for the development of Islamic insurance}

There has been a real rush for Takaful in recent years, and this can be explained by the following reasons: The boom in Islamic finance, the increase in the price of oil has generated a huge surplus in search of investment opportunities in the Middle and Far East, New infrastructure projects, as well as new cities or economic poles, and the increase in the number of expatriates in the Gulf countries; compulsory medical insurance (Saudi Arabia \& UAE) and automobile liability (Saudi Arabia); The emergence of a new, educated middle class, more aware of its insurance needs, has created a solvent demand for Shariacompliant alternatives; The low level of penetration (premiums / GDP) and density (premiums / head) and the number of Muslim populations are all opportunities for insurance in general, and require an adequate supply; In Muslim and Arab countries the penetration rates and density of insurance are very low, but the potential for growth is enormous.

\section{The basic principles of the Islamic financial system and the relation between Takaful and poverty}

The principle of the prohibition of interest that the interest or "riba" prohibited in Islam is not limited to usury but that it includes the interest paid on loans of all kinds whatever the order of size and use for which they are intended: ready for production or ready for consumption. The Sharia prohibits, in fact, any contractual premium on the amount of a loan of fungible goods (including currency). It also prohibits the withdrawal by the lender of any advantage from his loan, unless this advantage is freely granted by the borrower after repayment of the loan and without constituting a tacit or explicit condition. The search for the reasons for the prohibition of interest has given rise to certain interpretations, of which we can quote :Interest is prohibited because it constitutes a fixed contractual remuneration known in advance; Interest represents remuneration for time that should not be traded; The interest is unfair because it corresponds to a guaranteed remuneration from the lender, while the risks are fully assumed by the borrower (BID / IIRT). Moreover, the prohibition of interest is based on Koranic and prophetic texts on the one hand, but also on other texts from the sacred books of other revealed religions, namely Christianity and Judaism (Diouf).

The principle of the prohibition of uncertainty (GHAHAR) and speculation (MAYSIR).

Uncertainty about the terms of a financial contract is banished, but not the risk as such. In Islam, uncertainty means any exchange that is random or has something vague, imprecise, ambiguous, uncertain, hidden or dependent on some other event. For example, the Prophet forbade the purchase of an unborn animal (in its mother's womb), the sale of milk in the udder without measure, the purchase of what a fisherman caught before he caught it.

Speculation is also prohibited. It is about betting on the realization of an event based on subjective assessments of the future. For example games of chance, derivative contracts which are therefore difficult to envisage.

Illicit sectors; No financial transaction should be directed to non-Shariah compliant sectors. For example: alcoholic beverages, tobacco, gambling, pork industry, pornography, etc. For all of these sectors, intermediary activities are also illegal (marketing, distribution, packaging).

The principle of existence of an underlying asset; Any commercial transaction must be underpinned by an identifiable tangible asset. This principle projects Islamic microfinance into the "real economy". This corroborates the great classical and neoclassical theories which hold that the counterpart in economics of the money supply / financial flow. 
Sawssen Nafti., Saudi J Econ Fin, Jan, 2022; 6(1): 7-10

\section{CONCLUSION}

To conclude, Takaful insurance is a new kind of insurance, combining principles of conventional insurance, Islam and ethical values. It is clear that Takaful now appears to be a long-term trend, the most encouraging element in recent developments is the interest on the part of operators international organizations, which confirms the potential for Takaful in Muslim countries and also in Europe and North America. However, although poverty is partially reduced by charity and human rights of the poor paid by taxpayers in Arab countries and specifically by the Takaful and Zakat, the best way to reduce poverty is to create jobs. However, The funds collected by Zakat from taxpayers in the region must be targeted. On the contrary, it must provide an asset class capable of generating returns that will be subject to the Takaful and Zakat. However, Takaful constitute an effective solution to the problem of poverty and undernourishment in the long term.

\section{REFERENCES}

- BID / IIRT. (2006). "Introduction to Islamic Financing Techniques.” IIRT. Jeddah - SAUDI ARABIA, 1992

- "Creating an Islamic Microfinance Model: The Missing Dimension."

- Craig, R. N., \& David, M. E. (2012). Islamic Finance: Law and Practice, OUP Oxford.

- Dusuki, A. W. (2011). Islamic Financial System Principles \& Operations. International Shari'ah
Research, Academic for Islamic Finance (ISRA): Kuala Lumpur.

- Sahli, F. (2018). Les facteurs influençant le choix d'une assurance islamique en Tunisie», Revue Marocaine de recherche en management et marketing, $\mathrm{N}^{\circ} 18$, Juillet-Décembre.

- Gubert, F. (2011). Is microfinance a tool for poverty reduction? State of research. IRD.

- Mbacke, S. M. (2011). Impact of Islamic Microfinance in Poverty Reduction. MSC2 IAM end of study thesis. DAKAR.

- Serap, O. G. (2012). Takaful and Mutual Insurance, World Bank Publications.

- Jaffer, S. (2007). Islamic Insurance: Trends, Opportunities and the Future of Takaful, Linnius.

- Mher, M. H., \& Ahmad, T. P. (2011). Conceptual And Operational Differences Between Takaful General Insurance And Conventional Insurance. Australian Journal of Business and Management Research, 1(8), 23.

- Rahman, A. A., Ahmad, W. M. W., \& Buang, A. H. (2011). Can a takaful company reinsure with a reinsurance company? African Journal of Business Management, 5 (30), 11768-11778 Les Echos, Takaful this forgotten mutualism, 2015.

- Yusof, M. F. (1991). The concept and working system of Takaful. In Directory of Islamic Insurance (Takaful, 2000). London: Institute of Islamic Banking and Insurance. www.iium.edu.my/library.

- Abdelhakim, C. Dissertation on obtaining a magisterium in economics "Islamic finance, between opportunism and pragmatism". 